Quarterly Report

\title{
LOW SEVERITY UPGRADING OF F-T WAXES WITH SOLID SUPERACIDS
}

\author{
Principal Investigators \\ John W. Tierney \\ Irving Wender
}

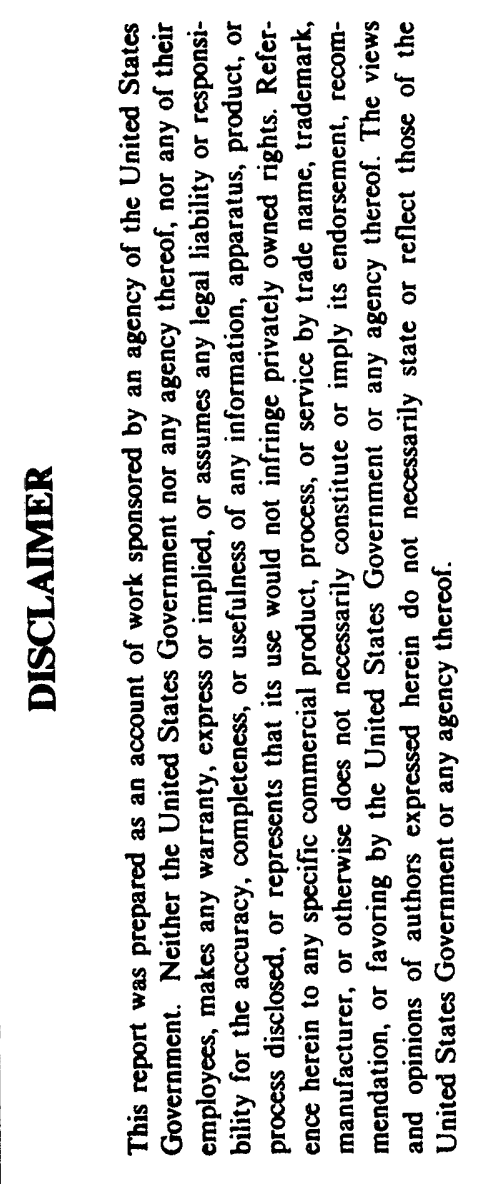

Department of Chemical and Petroleum Engineering

University of Pittsburgh, Pittsburgh, PA 15261

Prepared for the Department of Energy

Grant No. DE-FG22-91PC91304

September 1, 1993, through November 30, 1993

January 31, 1994 


\section{SUMMARY}

During the last quarter we characterized the acidity of platinum-promoted solid superacids by TPD (temperature-programmed desorption) and investigated the effect of sulfate concentration on the activity of $\mathrm{Pt} / \mathrm{ZrO}_{2} / \mathrm{SO}_{4}$ catalysts for isomerization and hydrocracking of $\mathrm{n}$-hexadecane. The activities of $\mathrm{Pt} / \mathrm{ZrO}_{2}$ promoted by different anions $\left(\mathrm{SO}_{4}{ }^{2-}, \mathrm{MoO}_{4}{ }^{2-}\right.$ and $\left.\mathrm{WO}_{4}{ }^{2-}\right)$, to give $\mathrm{Pt} / \mathrm{ZrO}_{2} / \mathrm{SO}_{4}, \mathrm{Pt} / \mathrm{ZrO}_{2} / \mathrm{MoO}_{4}$ and $\mathrm{Pt} / \mathrm{ZrO}_{2} / \mathrm{WO}_{4}$, were compared and the results related to their acidity and acid strength determined by TPD. TPD was an effective tool for the rapid evaluation of the acidity of metal-promoted solid superacids; this technique provided a good indication of the activity of the bifunctional solid superacids. The activity of the $\mathrm{Pt} / \mathrm{ZrO}_{2} / \mathrm{SO}_{4}$ catalyst at $160^{\circ} \mathrm{C}$ was compared with a $\mathrm{Pt} / \gamma-\mathrm{Al}_{2} \mathrm{O}_{3}$ reforming catalyst at $160^{\circ} \mathrm{C}$ and also at $400^{\circ} \mathrm{C}\left(350 \mathrm{psig} \mathrm{H}_{2}\right)$, respectively. The $\mathrm{Pt} / \gamma-\mathrm{Al}_{2} \mathrm{O}_{3}$ catalyst was not effective at $160^{\circ} \mathrm{C}$ but gave a $6.2 \mathrm{wt} \%$ conversion of the n-hexadecane to isomerized and cracked products at $400^{\circ} \mathrm{C}$.

The isomerization and hydrocracking of long-chain paraffins over metal-promoted solid superacids were carried out in the presence of selected aromatic compounds. It appears that the presence of aromatics changes the surface acidity of the catalyst, resulting in higher molecular weight products (from $\mathrm{C}_{4}-\mathrm{C}_{9}$ to $\mathrm{C}_{10}-\mathrm{C}_{16}$ ) from $\mathrm{n}$-hexadecane. This finding is important in obtaining a more desirable product distribution from hydrocracking of $\mathrm{F}-\mathrm{T}$ waxes.

\section{EXPERIMENTAL}

\section{TPD Characterization}

TPD experiments were performed using a fixed-bed reactor with a modified GC (Varian 3300 ) as detector. Before introducing the adsorbate, the catalyst was preheated at $450^{\circ} \mathrm{C}$ for one hour in dry air. The adsorptions were conducted by introducing pyridine into the reactor through 
a saturator at $160^{\circ} \mathrm{C}$. He was used as carrier gas. After adsorption, the He flow was continued for an additional 20 minutes to remove excess pyridine. The reactor temperature was then raised at a rate of $10^{\circ} \mathrm{C} \mathrm{min}^{-1}$ to $800^{\circ} \mathrm{C}$, and maintained at this temperature for 10 minutes. The desorbed gases were analyzed by a thermal conductivity detector (TCD) and occasionally analyzed by GC-MS (HP-5970 II).

\section{Effect of Sulfuric Acid Concentration on Activity of $\mathrm{Pt} / \mathrm{ZrO}_{2} / \mathrm{SO}_{4}$ Catalysts}

$\mathrm{Pt} / \mathrm{ZrO}_{2} / \mathrm{SO}_{4}$ catalysts with different sulfate contents were prepared by sulfation of $\mathrm{Zr}(\mathrm{OH})_{4}$ with various concentration of sulfuric acid. The $\mathrm{Zr}(\mathrm{OH})_{4}$ was prepared by hydrolyzing aqueous solutions of $\mathrm{ZrOSO}_{4} \cdot 3 \mathrm{H}_{2} \mathrm{O}$ with $28.5 \mathrm{wt} \% \mathrm{NH}_{4} \mathrm{OH}$ solution at room temperature. The precipitates were washed, dried at $100^{\circ} \mathrm{C}$ overnight and further treated by $0.5-6.0 \mathrm{~N} \mathrm{H}_{2} \mathrm{SO}_{4}$ solution for one hour at room temperature using $15 \mathrm{ml}$ of solution per gram of solid. Platinum was impregnated after sulfation. All the catalysts were then calcined at $600^{\circ} \mathrm{C}$ for three hours. The activity of these catalysts was measured by isomerization and hydrocracking of $n$-hexadecane at $160^{\circ} \mathrm{C}$ and 350 psig $\mathrm{H}_{2}$ in a microreactor.

\section{Anion-Modified $\mathrm{Pt} / \mathrm{ZrO}_{2}$ Catalysts}

The procedures employed in the preparation of $\mathrm{Pt} / \mathrm{ZrO}_{2} / \mathrm{MoO}_{4}$ and $\mathrm{Pt} / \mathrm{ZrO}_{2} / \mathrm{WO}_{4}$ catalysts were similar to those employed in preparing the $\mathrm{Pt} / \mathrm{ZrO}_{2} / \mathrm{SO}_{4}$ catalyst, except for the incorporation of $\mathrm{MoO}_{4}{ }^{2-}$ and $\mathrm{WO}_{4}{ }^{2-}$ ions. $\mathrm{A} \mathrm{Pt} / \mathrm{ZrO}_{2} / \mathrm{WO}_{4}$ catalyst was obtained by impregnating $\mathrm{Zr}(\mathrm{OH})_{4}$ with aqueous ammonium metatungstate followed by removal of water at $110^{\circ} \mathrm{C}$. Platinum was then impregnated and the catalyst calcined in air at $800-850^{\circ} \mathrm{C}$ for 2 hours. The $\mathrm{Pt} / \mathrm{ZrO}_{2} / \mathrm{MoO}_{4}$ catalyst was obtained by impregnating $\mathrm{Zr}(\mathrm{OH})_{4}$ with molybdic acid followed by impregnation with $\mathrm{Pt}$ and 
calcination in air at $650^{\circ} \mathrm{C}$. The elemental Mo and $\mathrm{W}$ contents in the two catalysts were each 5.0 wt\%.

A reforming catalyst, $\mathrm{Pt} / \gamma-\mathrm{Al}_{2} \mathrm{O}_{3}$, containing $5.0 \mathrm{wt} \%$ of $\mathrm{Pt}$ was purchased from Aldrich Chemical, Inc. The catalyst was preheated at $400^{\circ} \mathrm{C}$ before reaction to remove physically adsorbed moisture.

\section{RESULTS AND CONCLUSIONS}

Characterization of the Acidity and Acid Strength of Metal-Promoted Solid Superacids

We define acidity and acid strength as follows: acidity is proportional to the number of acid sites while acid strength is the ability of a protonic acid site to donate a proton, or the ability of a Lewis acid site to attract electrons. We used TPD to measure both acidity and acid strength by relating them to the amount of pyridine desorbed and the temperature of desorption. We found that this was consistent with catalytic behavior in a microreactor.

A TPD spectrum for pyridine adsorption on $\mathrm{Pt} / \mathrm{ZrO}_{2} / \mathrm{SO}_{4}$ is shown in Figure 1. An asymmetric peak at $230^{\circ} \mathrm{C}$ (within $200-300^{\circ} \mathrm{C}$ ) was observed. This characteristic is consistent with in-situ FT-IR measurements. As shown in Figure 2, strong adsorptions of both Lewis (1491 $\left.\mathrm{cm}^{-1}\right)$ and Bronsted acid sites $\left(1548 \mathrm{~cm}^{-1}\right)$ appear upon saturation of $\mathrm{Pt} / \mathrm{ZrO}_{2} / \mathrm{SO}_{4}$ catalyst with pyridine. The desorption of pyridine (decrease in peak intensity of the Lewis and Bronsted acid sites) starts at $200^{\circ} \mathrm{C}$ and is completed at $300^{\circ} \mathrm{C}$. To assure that this peak is not generated by decomposition or from gases formed from the interaction between pyridine and catalyst, a gas sample was taken at $250^{\circ} \mathrm{C}$ during the TPD measurement. This sample was injected into a GCMS (HP 5790 II) and found to contain only pyridine. The correspondence between TPD measurement and in-situ FT-IR analysis indicates that the TPD peak at around $230^{\circ} \mathrm{C}$ is an 
indication of the nature of Lewis and Bronsted acid sites. A small, broad and asymmetric peak at $430^{\circ} \mathrm{C}$ (within $350-490^{\circ} \mathrm{C}$ ) was also observed. This suggests that the catalyst surface contains small amounts of nonuniform acid sites with higher acid strengths. GC-MS analysis showed that the gas sample taken at $450^{\circ} \mathrm{C}$ was a mixture of pyridine and $\mathrm{SO}_{2}$, indicating that decomposition of sulfate groups begins at temperature near $450^{\circ} \mathrm{C}$. It appears that the desorption temperature of the peak at $\left(230^{\circ} \mathrm{C}\right)$ and its intensity are measures of acid strength and acidity of these metalpromoted solid superacids.

The catalytic isomerization and hydrocracking of n-hexadecane were used as test reactions to obtain a measure of the superacidic character of these anion promoted oxides; the results are summarized in Table 1. As expected, $\mathrm{Pt} / \mathrm{ZrO}_{2} / \mathrm{SO}_{4}$, with both the highest acidity and acid strength, gives the highest conversion for hydrocracking of $n$-hexadecane. This correspondence between the acidity and activity indicates that TPD may be developed as an effective method to evaluate the superacidity of metal-promoted solid superacids.

\section{Effect of the Concentration of $\mathrm{H}_{2} \mathrm{SO}_{4}$ on Catalytic Activity}

It is generally believed that the strong acidity of sulfated solid superacids is generated from the induction effect of the $\mathrm{SO}_{4}^{2-}$ group in the catalyst. As shown in Figure 3, the sulfate contents of $\mathrm{Pt} / \mathrm{ZrO}_{2}$ treated with various concentrations of $\mathrm{H}_{2} \mathrm{SO}_{4}$ solutions do not change after calcination at $600^{\circ} \mathrm{C}$ for three hours. The activities of the $\mathrm{Pt} / \mathrm{ZrO}_{2} / \mathrm{SO}_{4}$ catalysts treated with $1.0 \mathrm{~N}$ to $4.0 \mathrm{~N}$ sulfuric acid are almost the same. The decrease in activity for the sample treated with $6.0 \mathrm{~N}$ sulfuric acid may be due to blocking of the surface with excess $\mathrm{SO}_{4}{ }^{2-}$ during sulfation or modification of the catalyst caused by excess $\mathrm{SO}_{4}{ }^{2-}$. 
Comparison of the Activity of $\mathrm{Pt} / \mathrm{ZrO}_{2} / \mathrm{SO}_{4}$ and $\mathrm{Pt} / \mathrm{Al}_{2} \mathrm{O}_{3}$ catalysts in Hydrocracking Paraffins

$\mathrm{Pt} / \mathrm{Al}_{2} \mathrm{O}_{3}$ has been used commercially as a cracking and reforming catalyst. This catalyst is effective only at high temperatures $\left(>500^{\circ} \mathrm{C}\right)$. We compared the activity of the $\mathrm{Pt} / \gamma-\mathrm{Al}_{2} \mathrm{O}_{3}$ catalyst with platinum-promoted solid superacids at $160^{\circ} \mathrm{C}$, and 350 psig. The results are summarized in Table 2. At $160^{\circ} \mathrm{C}$, the $\mathrm{Pt} / \gamma-\mathrm{Al}_{2} \mathrm{O}_{3}$ is inactive; however, about a $6.2 \mathrm{wt} \%$ conversion was observed at $409^{\circ} \mathrm{C}$ with $\mathrm{Pt} / \gamma-\mathrm{Al}_{2} \mathrm{O}_{3}$ catalyst yielding cracked products containing normal and monobranched paraffins. At $160^{\circ} \mathrm{C}$ on a $\mathrm{Pt} / \mathrm{ZrO}_{2} / \mathrm{SO}_{4}$ catalyst, an $83.8 \mathrm{wt} \%$ total conversion was reached and the products contained highly branched paraffins. Considering that both catalysts contain platinum, it is obvious that the acidity of $\mathrm{ZrO}_{2} / \mathrm{SO}_{4}$ plays a key role in hydrocracking of paraffins. The difference in product distribution obtained from the catalysts implies that the reactions occur through different pathways.

\section{Effect of Aromatics on the Product Distribution from Hydrocracking of Paraffins}

F-T waxes contain mainly paraffins with small amounts of olefins. It is well known that upgrading of paraffins on solid superacids involves carbocation intermediates. These carbocations may be captured by electron rich compounds such as aromatics. We found that paraffins alkylated aromatic rings, a reaction of great interest.

This finding led to an exploration of the effect on product distribution of the addition of aromatics to long-chain paraffins. The results are shown in Table 3. The presence of $5 \mathrm{wt} \%$ of toluene significantly inhibits isomerization and hydrocracking activity of the $\mathrm{Pt} / \mathrm{ZrO}_{2} / \mathrm{SO}_{4}$ catalyst; total conversion drops from $75.4 \mathrm{wt} \%$ to $25.4 \mathrm{wt} \%$. Evidently, the electron-rich toluene captures protonic acid sites responsible for hydrocracking of paraffins.

The presence of toluene changed the product distribution, giving a $52.2 \%$ selectivity to 
isohexadecane. Toluene weakens the acidity of the $\mathrm{Pt} / \mathrm{ZrO}_{2} / \mathrm{SO}_{4}$ catalyst, preventing further cracking. In a batch reactor, the competitive adsorption of aromatics and paraffins on protonic acid sites is difficult to control; aromatics will occupy most of the protonic acid sites, inhibiting the protonation of paraffins. Use of a continuous flow fixed-bed reactor may give different results since the residence time of aromatics and paraffins on the catalyst surface can be monitored.

\section{FUTURE WORK}

$\mathrm{ZrO}_{2}, \mathrm{ZrO}_{2} / \mathrm{SO}_{4}$ and $\mathrm{Pt} / \mathrm{ZrO}_{2} / \mathrm{SO}_{4}$ derived from $\mathrm{ZrO}_{2}$ aerogels synthesized under $\mathrm{CO}_{2}$ supercritical conditions will be provided by Carnegie Mellon University and will be tested as catalysts for isomerization and hydrocracking of $\mathrm{n}$-hexadecane. Their activity will be compared with $\mathrm{Pt} / \mathrm{ZrO}_{2} / \mathrm{SO}_{4}$ catalysts prepared by conventional methods. These catalysts will be characterized by TPD and in situ FT-IR to gain insights into the nature of the acidity and acid strength of metal-promoted solid superacids.

TPD measurements will be continued with weak basic compounds such as benzene and xylene as adsorbents to probe surface acidities. The TPD measurement coupled with in-situ FT-IR analysis will be carried out to provide a better understanding of the chemistry occurring on metalpromoted solid superacids.

A kinetic model will be derived and fitted with experimental data. This model will be used to help define the reaction chemistry involved in isomerization and hydrocracking of long-chain paraffins. 
Table 1. Effect of Anion Functional Groups on Catalytic Activity and Acidity of $\mathrm{Pt} / \mathrm{ZrO}_{2}$

\begin{tabular}{|c|c|c|c|}
\hline Catalysts & $\mathrm{n}-\mathrm{C}_{16}$ conversion (wt\%) & Acidity (mol/g) & $\mathrm{T}_{\mathrm{d}}{ }^{\circ}\left({ }^{\circ} \mathrm{C}\right)$ \\
\hline $\mathrm{Pt} / \mathrm{ZrO}_{2} / \mathrm{SO}_{4}$ & 83.9 & 0.358 & 290.2 \\
\hline $\mathrm{Pt} / \mathrm{ZrO}_{2} / \mathrm{WO}_{4}$ & 1.0 & 0.144 & 283.0 \\
\hline $\mathrm{Pt} / \mathrm{ZrO}_{2} / \mathrm{MO}_{4}$ & none & 0.085 & 257.3 \\
\hline
\end{tabular}

* Desorption temperature at maximum intensity.

Table 2. Comparison of Hydrocracking Activity of $\mathrm{Pt} / \mathrm{ZrO}_{2} / \mathrm{SO}_{4}$ and $\mathrm{Pt} / \gamma-\mathrm{Al}_{2} \mathrm{O}_{3}$ Catalysts

\begin{tabular}{|c|c|c|}
\hline Catalysts & \multicolumn{2}{|c|}{ Reaction Conditions and Product Type } \\
\hline $\mathrm{Pt} / \mathrm{ZrO}_{2} / \mathrm{SO}_{4}$ & $\begin{array}{l}160^{\circ} \mathrm{C}, 350 \text { psig of } \mathrm{H}_{2}, 60 \mathrm{~min}, \\
\text { total conversion } 83.8 \mathrm{wt} \%\end{array}$ & $\begin{array}{cc}\text { Selectivity: } & \text { (multibranched) } \\
\mathrm{C}_{4}-\mathrm{C}_{9} & 71.2 \\
\mathrm{C}_{10}-\mathrm{C}_{13} & 18.6 \\
\text { iso- } \mathrm{C}_{16} & 10.2 \\
\end{array}$ \\
\hline \multirow[t]{2}{*}{$\mathrm{Pt} / \gamma-\mathrm{Al}_{2} \mathrm{O}_{3}$} & $\begin{array}{l}160^{\circ} \mathrm{C}, 350 \mathrm{psig} \text { of } \mathrm{H}_{2}, 60 \mathrm{~min}, \\
\text { no conversion }\end{array}$ & $-\cdots--$ \\
\hline & $\begin{array}{l}00^{\circ} \mathrm{C}, 350 \text { psig of } \mathrm{H}_{2}, 60 \mathrm{~min} \\
\text { total conversion } 6.2 \mathrm{wt} \%\end{array}$ & $\begin{array}{lll}\begin{array}{l}\text { Selectivity: } \\
\text { (monobranched }\end{array} & \mathrm{C}_{4}-\mathrm{C}_{9} & 44.5 \\
\text { and normal) } & \mathrm{C}_{10}-\mathrm{C}_{14} & 23.0 \\
& \mathrm{C}_{16} & 32.5 \\
\end{array}$ \\
\hline
\end{tabular}


Table 3. Effect of Toluene on Product Distribution in Hydrocracking of $n$-hexadecane

\begin{tabular}{|c|c|c|}
\hline $\begin{array}{l}\text { Temperature } \\
\text { Pressure } \\
\text { Reaction Time } \\
\text { Feed/Catalyst } \\
\end{array}$ & & $\begin{array}{l}160^{\circ} \mathrm{C} \\
350 \text { psig } \\
60 \text { minutes } \\
6.0 \\
\end{array}$ \\
\hline \multicolumn{3}{|c|}{ Product Distribution } \\
\hline & Absence of Toluene & Presence of Toluene (5wt\%) \\
\hline $\begin{array}{l}\text { Total Conversion } \\
\text { Selectivity: }\end{array}$ & $75.4 \mathrm{wt} \%$ & $25.4 \mathrm{wt} \%$ \\
\hline $\mathrm{C}_{4}-\mathrm{C}_{9}$ & 67.8 & $27.4^{*}$ \\
\hline $\mathrm{C}_{10}-\mathrm{C}_{13}$ & 23.4 & 20.4 \\
\hline iso- $\mathrm{C}_{16}$ & 9.8 & 52.2 \\
\hline
\end{tabular}




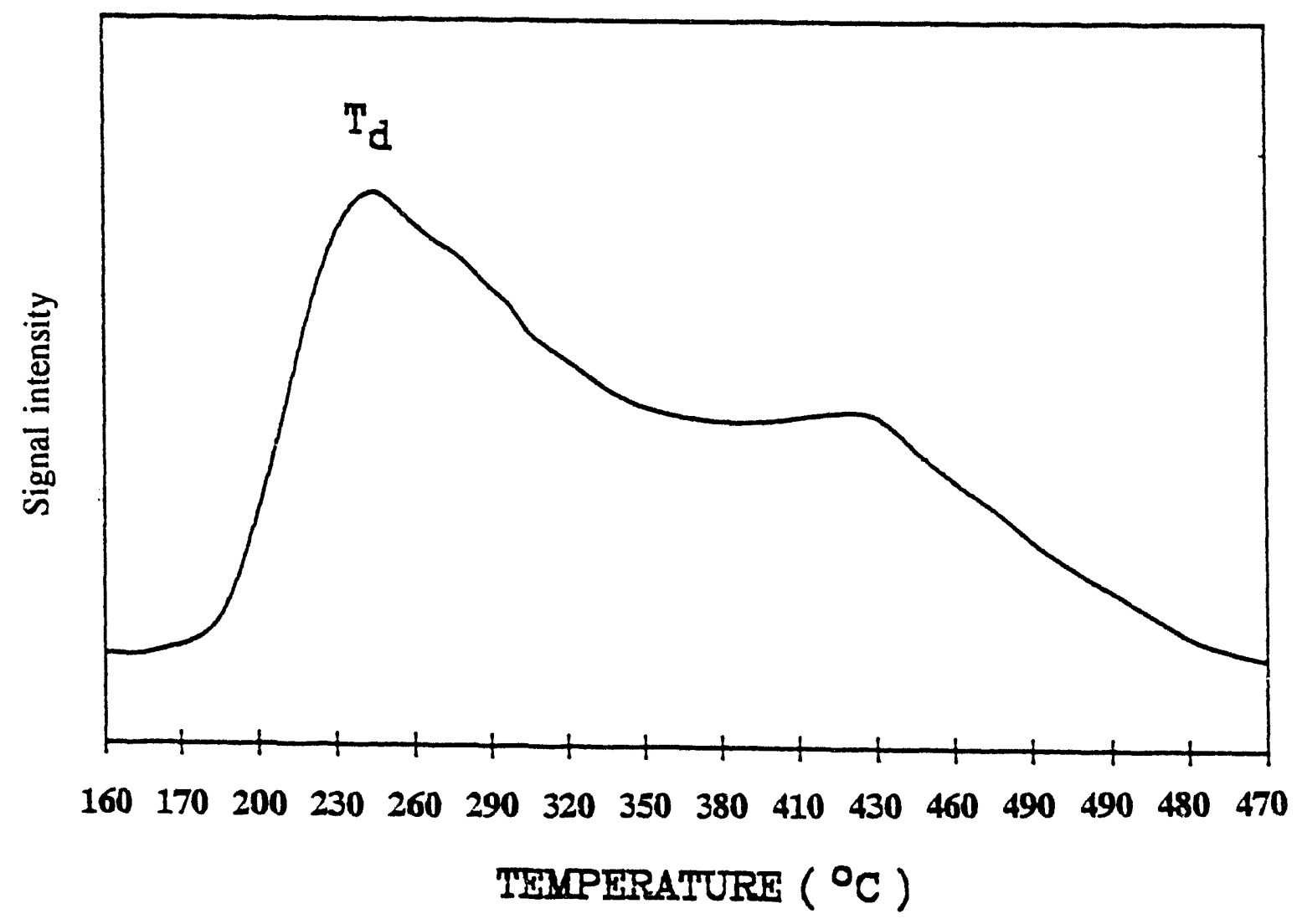

Figure 1. TPD spectrum of pyridine-adsorbed $\mathrm{Pt} / \mathrm{ZrO} / \mathrm{SO}_{4}$ catalyst 


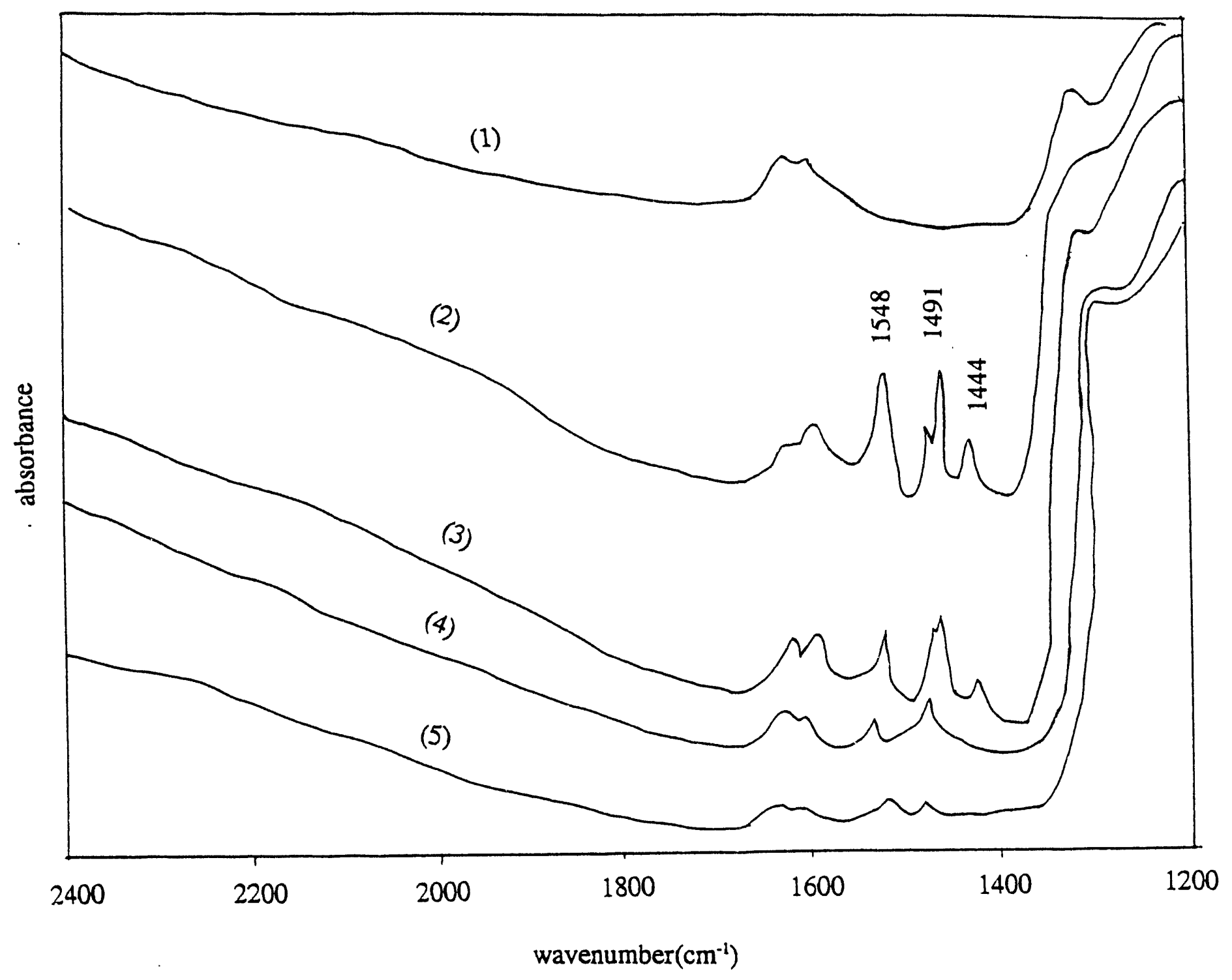

Figure 2. Desorption of pyridine from $\mathrm{Pt} / \mathrm{ZrO}_{2} / \mathrm{SO}_{4}$ catalyst observed by in-situ FT-IR

(1) before introducing pyridine

(2) adsorption of pyridine at $150^{\circ} \mathrm{C}$

(3) desorption of pyridine, at $200^{\circ} \mathrm{C}$

(4) desorption of pyridine at $250^{\circ} \mathrm{C}$

(5) desorption of pyridine at $300^{\circ} \mathrm{C}$ 


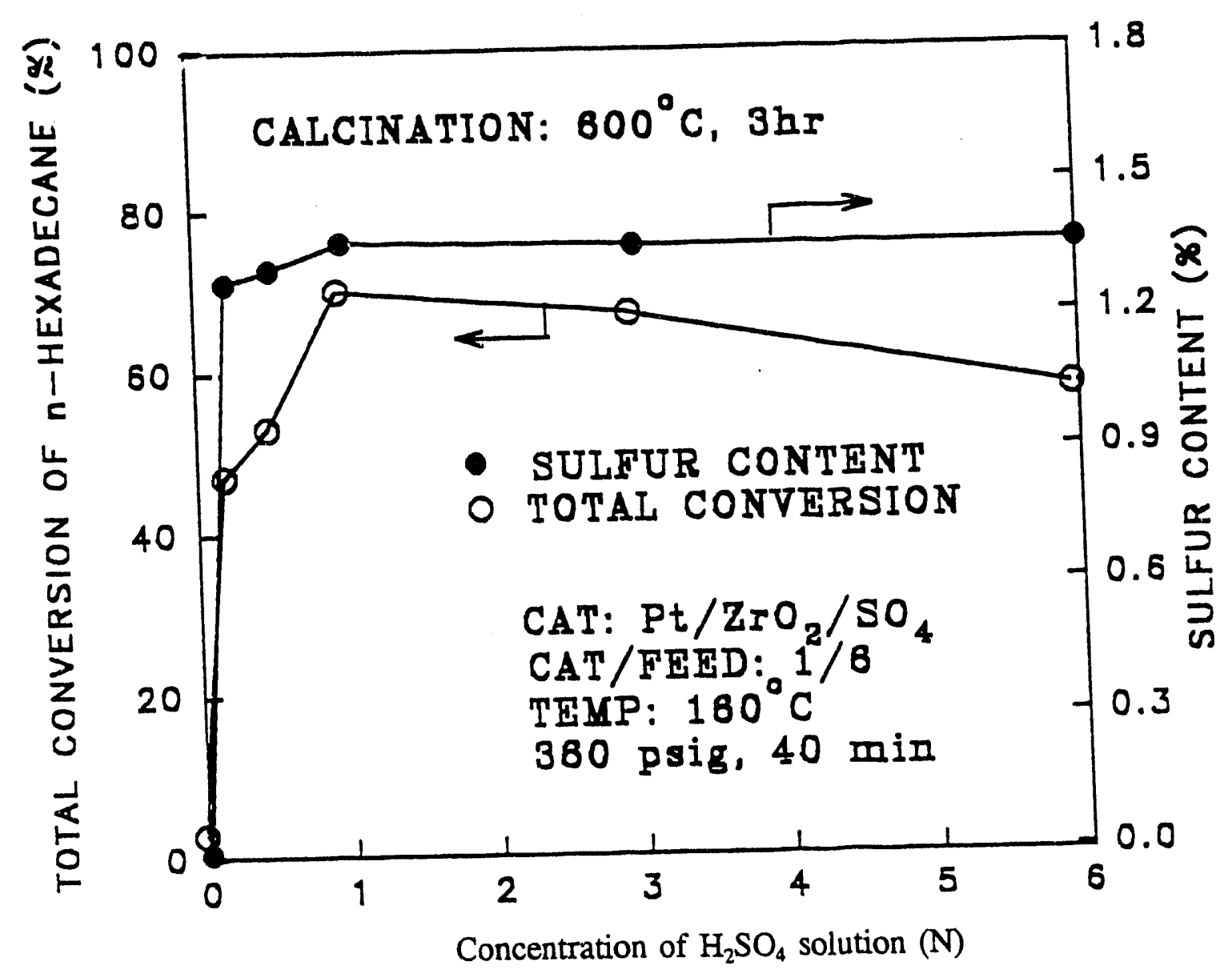

Figure 3. Effect of the concentraticn of sulfation solution on catalytic activity of $\mathrm{Pt} / \mathrm{ZrO}_{2} / \mathrm{SO}_{4}$ catalyst 

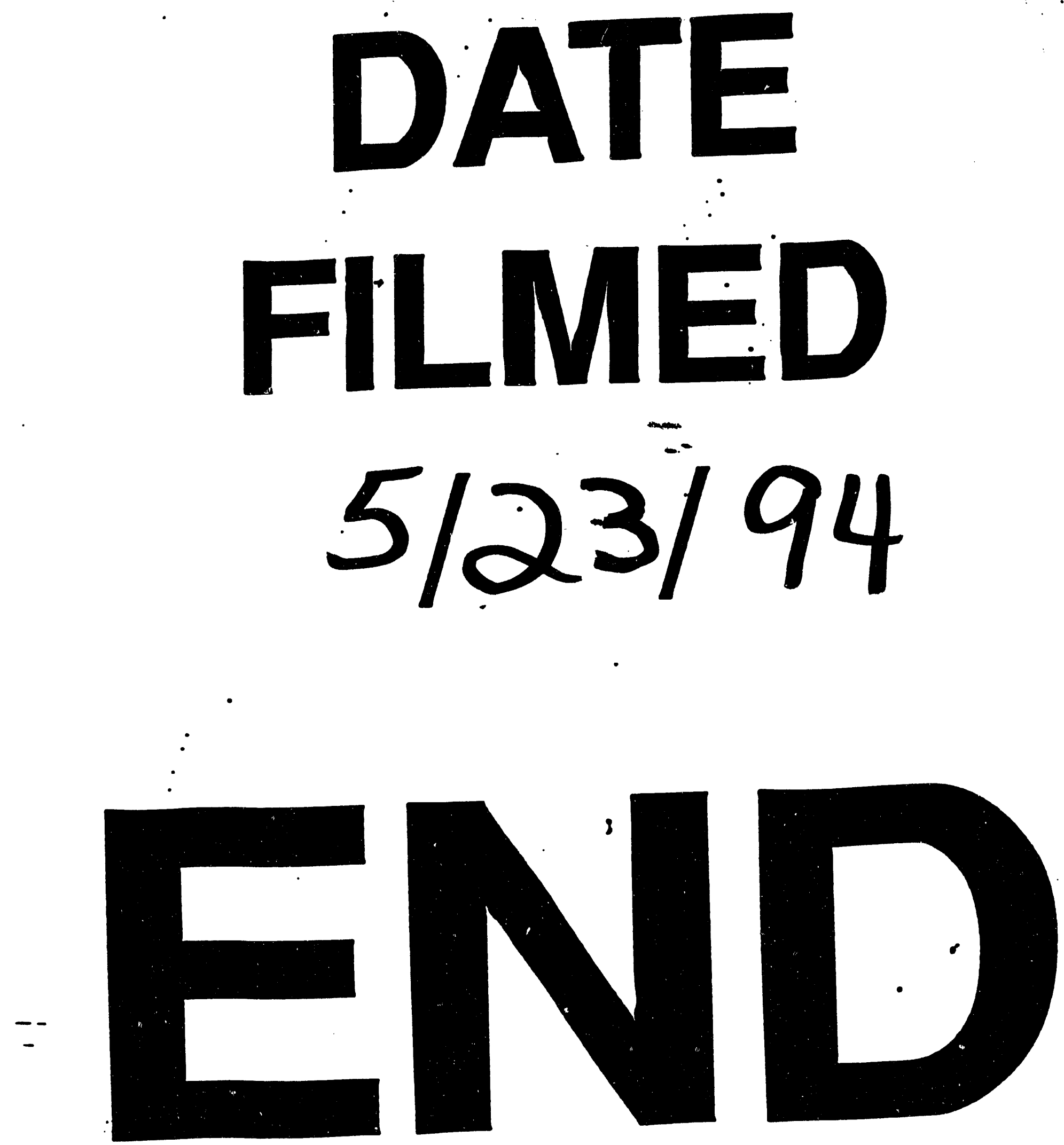


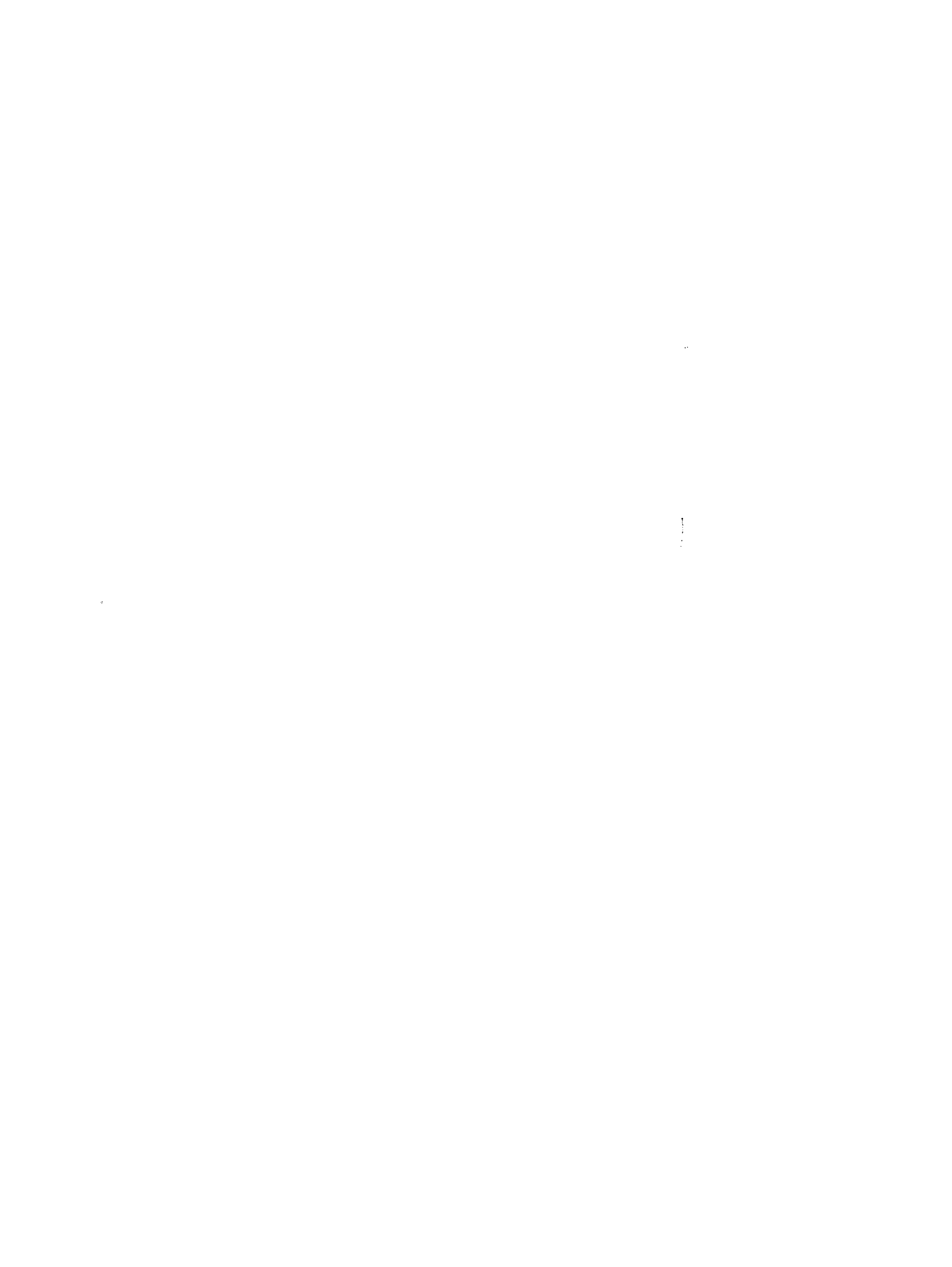

